\title{
Natural regulation of Delia radicum in organic cabbage production
}

\author{
Nicolai V. Meyling ${ }^{\mathrm{a}, *}$, Søren Navntoft ${ }^{\mathrm{a}}$, Holger Philipsen ${ }^{\mathrm{a}}$, Kristian Thorup-Kristensen ${ }^{\mathrm{b}, 1}{ }^{,}$Jørgen Eilenberg $^{\mathrm{a}}$
}

${ }^{a}$ Department of Agriculture and Ecology, University of Copenhagen, Thorvaldsensvej 40, DK-1871 Frederiksberg C, Denmark

b Department of Horticulture, Aarhus University, Kirstinebjergvej 10, DK-5792 Aarslev, Denmark

\section{A R T I C L E I N F O}

\section{Article history:}

Received 14 March 2012

Received in revised form

26 September 2012

Accepted 27 September 2012

\section{Keywords:}

Pest management

Organic fertilizer

Trybliographa rapae

Staphylinidae

Carabidae

\begin{abstract}
A B S T R A C T
In a field experiment, we evaluated effects of three different organic white cabbage-cropping systems $(01,02,03)$ on the cabbage root fly, Delia radicum, and its egg predators and pupal parasitoids over 3 years. The three systems all complied with regulations for organic production, but varied in external nutrient input and $\mathrm{N}$-recycling, and were compared to a conventionally farmed control. One organic system (03) included an intercropped strip of green manure between crop rows. Oviposition by $D$. radicum was generally not reduced in organic cropping systems. However, higher pupae/egg ratios were observed in the conventional compared to all organic systems, indicating that immature survival from oviposition to pupation was reduced under all the three organic farming practices. In organic system $\mathrm{O} 2$ most small coleopteran predators were recorded, but predation on fly eggs was not significantly higher in organic treatments. Pupal parasitization rates ranged from $26.5 \%$ to $59.5 \%$, but no significant differences among farming systems were found. Although reduced $D$. radicum survival could not be attributed solely to natural enemies, the results indicated that organic farming practices in general contribute to the suppression of belowground pests in cabbage production.
\end{abstract}

(c) 2012 Elsevier B.V. All rights reserved.

\section{Introduction}

The cabbage root fly Delia radicum (L.) (Diptera: Anthomyiidae) is a major belowground pest in brassicaceous vegetables in northern Europe (Finch and Collier, 2000b; Hooks and Johnson, 2003) and management practices must be implemented to control this pest (Zehnder et al., 2007). Intercropping with, e.g. clover has proved to be an efficient pest management strategy reducing oviposition by D. radicum (Finch and Collier, 2000a,b; Hooks and Johnson, 2003). Eggs of $D$. radicum are preyed upon by various small ground dwelling predatory beetles including carabids and staphylinids (Wishart et al., 1956; Hughes, 1959; Finch, 1996; Prasad and Snyder, 2004). The predation on eggs contributes to biological control of root flies (e.g. Finch, 1996; Bjorkman et al., 2010). Moreover, larvae of $D$. radicum are attacked by the parasitoids Trybliographa rapae (Westwood) (Hymenoptera: Figitidae) and Aleochara bilineata (Gyll.) (Coleoptera: Staphylinidae) (Finch and Skinner, 1980; Jones et al., 1993). The two parasitoid species usually co-occur, collectively contributing to the regulation of $D$. radicum (Bonsall et al., 2004; Hummel et al., 2010).

\footnotetext{
* Corresponding author. Tel.: +45 3533 2666; fax: +45 35332670.

E-mail address: nvm@life.ku.dk (N.V. Meyling).

1 Present address: Department of Agriculture and Ecology, University of Copenhagen, Højbakkegårds allé 13, DK-2630 Taastrup, Denmark.
}

Organic farming generally benefits natural enemy performance and abundance (Birkhofer et al., 2008; Garratt et al., 2011) and enhances characteristics of natural enemy communities that may result in improved biological pest control compared to conventional farming (Crowder et al., 2010). However, increasing diversity of natural enemies through, e.g. habitat management (Landis et al., 2000) may not result in enhanced biological pest control due to increased niche overlap and/or intraguild predation (Straub et al., 2008; Prasad and Snyder, 2006).

Organic fertilizer methods have profound effects on aboveground pests (Eigenbrode and Pimentel, 1988; Alyokhin et al., 2005; Birkhofer et al., 2008; Hsu et al., 2009; Garratt et al., 2010; Staley et al., 2010) with manures showing consistent negative effects while composts have positive effects (Garratt et al., 2011). However, effects on root feeding herbivores have received limited attention. Furthermore, effects of manure applied as organic fertilizer on natural enemies are poorly investigated (Garratt et al., 2011). Organic farmers can reduce the application of animal manures (e.g. slurry) by combining with green manures prior to crop planting. As intercropping can be implemented as a pest management tool for D. radicum (Finch and Collier, 2000b), conserving strips of green manure between the crops could provide the benefits of intercropping on $D$. radicum oviposition as well as providing habitat refuges for predators (Landis et al., 2000), also between seasons until the time of cabbage establishment.

In the present study we wished to evaluate the effects of organic farming practices of white cabbage compared to a conventional 
Table 1

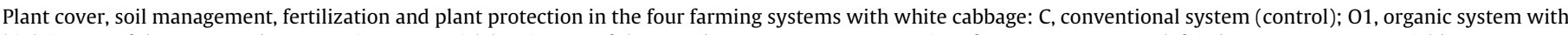

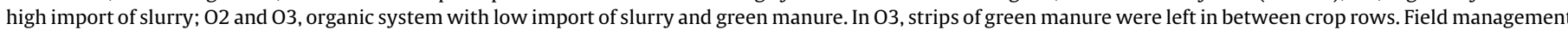
followed approximately similar schedules each year.

\begin{tabular}{|c|c|c|c|c|c|}
\hline \multirow[t]{2}{*}{ Treatment } & & \multicolumn{4}{|l|}{ Farming system } \\
\hline & & $\mathrm{C}$ & 01 & $\mathrm{O} 2$ & $\mathrm{O} 3$ \\
\hline Undersowing & & No & No & Lucerne/red clover & $\begin{array}{l}\text { Bird's foot } \\
\text { trefoil/ryegrass }\end{array}$ \\
\hline \multirow[t]{3}{*}{ Soil } & $\begin{array}{l}\text { Ploughing (green manure } \\
\text { incorporation) }\end{array}$ & November & November & March & \\
\hline & $\begin{array}{l}\text { Rotovation (incorporation of green } \\
\text { manure in rows) }\end{array}$ & & & & November \\
\hline & $\begin{array}{l}\text { Rotovation repeated plus loosening } \\
\text { of soil }\end{array}$ & & & & April/May \\
\hline \multirow[t]{2}{*}{ Establishment } & Sowing ${ }^{\mathrm{b}}$ & April & April & April & April \\
\hline & $\begin{array}{l}\text { Transplanting cabbage to the field } \\
\text { plots }\end{array}$ & May & May & May & May \\
\hline \multirow[t]{2}{*}{ Fertilizer } & NPK (21\%N, 3\%P, 10\%K) & $310 \mathrm{~kg} \mathrm{~N} \mathrm{ha}^{-1 \mathrm{c}}$ & & & \\
\hline & Pig slurry & & April (225 kg N ha $\left.{ }^{-1}\right)$ & April (135 kg N ha-1) & April (135 kg N ha $\left.{ }^{-1}\right)$ \\
\hline \multirow[t]{5}{*}{ Pest control } & $\begin{array}{l}\text { Azoxystrobin (synthetic fungicide, } \\
\text { Amistar }^{\circledR} \text { ) }\end{array}$ & $750 \mathrm{~g} \mathrm{ha}^{-1 \mathrm{~d}}$ & & & \\
\hline & Bacillus thuringiensis var. kurstaki ${ }^{\mathrm{e}}$ & $3-4 l \mathrm{ha}^{-1 \mathrm{f}}$ & $3-41 \mathrm{ha}^{-1 \mathrm{f}}$ & $3-41 \mathrm{ha}^{-1 \mathrm{f}}$ & $3-41 \mathrm{ha}^{-1 \mathrm{f}}$ \\
\hline & Alpha-cypermethrin (synthetic & $20 \mathrm{~g} \mathrm{ha}^{-1}$ (June 2007) & & & \\
\hline & insecticide, Fastac $50^{\circledR}$ ) & $60 \mathrm{~g} \mathrm{ha}^{-1}(2008-2009)^{\mathrm{g}}$ & & & \\
\hline & $\begin{array}{l}\text { Pirimicarb (synthetic insecticide, } \\
\text { Pirimor } G^{\circledR} \text { ) }\end{array}$ & $250 \mathrm{~g} \mathrm{ha}^{-1 \mathrm{~h}}$ & & & \\
\hline \multicolumn{2}{|l|}{ Harvest } & October & October & October & October \\
\hline
\end{tabular}

farming practice on: (i) oviposition of $D$. radicum in white cabbage; (ii) the relationship between oviposition and pupal production; (iii) predation rates on fly eggs; (iv) abundance of potential egg predators; and $(\mathrm{v})$ parasitization rates by and relative species abundance of parasitoids in $D$. radicum puparia. We included three different organic farming systems, all of which complied with official requirements for being certified as "organic". In addition, a fourth system (control) was conventionally farmed. All four systems included the same crop rotation of main crops, but the three organic systems differed in reliance on external nutrient input and nutrient recycling from pure import of high amount of slurry to low slurry import combined with green manures. One of the organic practices included an intercropped strip of the green manure between crop rows.

\section{Materials and methods}

The experimental farming systems were located at a research farm in Årslev $\left(10^{\circ} 27^{\prime} \mathrm{E}, 55^{\circ} 18^{\prime} \mathrm{N}\right)$, Denmark, and maintained as a field experiment over four seasons from 2006 to 2009. White cabbage (Brassica oleracea L. convar. capitata (L.) Alef. var. alba DC 'Impala') was grown as a part of an experimental rotation with other vegetables and cereals, and cabbage always followed winter rye (Secale cereale L.). Crops were grown using four different farming practices (see Table 1 and Thorup-Kristensen et al., 2012). One was a conventionally farmed system (C) with application of both synthetic fertilizer and chemical pesticides, and three were organic systems: (01) dependent on high external input of organic fertilizer (slurry) and without undersowing green manure and no nutrient recycling; (O2) low external input of organic fertilizer (slurry), undersown green manure and nutrient cycling using catch crops; and (03) low external input of organic fertilizer (slurry), green manure and catch crops as in 02 , but with the difference that strips of the previous year's green manure were left in between the crop rows. In $\mathrm{O} 2$ a green manure mixture of lucerne (Medicago sativa L.) and red clover (Trifolium pratense L.) was established in the rye crop in spring and incorporated in late autumn before the cabbage crops, whereas in $\mathrm{O} 3$ the green manure consisted of a mixture of bird's foot trefoil (Lotus corniculatus L.) and ryegrass (Lolium perenne L.), to achieve a less aggressive competition from the strips of green manure when growing between the cabbage rows (Båth et al., 2008). This meant that in $\mathrm{O} 3$ two rows of cabbage alternated with one strip of green manure whereas the three other systems had three crop rows on the similar area. The crops were grown in experimental plots of $10 \mathrm{~m} \times 12.5 \mathrm{~m}$, and each plot was prepared with seven beds each planted with three crop rows. Each row contained 16 plants. All experimental plots in the complete crop rotation (eight plots, see Thorup-Kristensen et al., 2012) receiving each of the four farming practices measured $10 \mathrm{~m} \times 130 \mathrm{~m}$, and each of these were separated by $8 \mathrm{~m}$ to the neighbouring treatment. Permanent grass was established between treatments in mid May each year. Distances between individual plots planted with white cabbage in the four treatments varied from 8 to $80 \mathrm{~m}$ depending on year due to the rotation. The experimental treatments were replicated in three fields (blocks) within the same experimental farm separated by distances of $75-100 \mathrm{~m}$.

Cabbage seeds were coated with a mixture of thiram/carbendazin/iprodione/metalaxyl- $m$ in the conventional system. In all four systems, plants were grown from seeds in the greenhouse and transplanted to the field in mid May, thus avoiding the peak flight period of the first generation of $D$. radicum. Small white Pieris rapae (L.) (Lepidoptera: Pieridae) larvae were controlled with Bacillus thuringiensis (Bt) var. kurstaki (Dipel ES ${ }^{\circledR}$ ) when needed in all cabbage plots in accordance with Danish regulation for organic farming. Weeds were controlled with mechanical weeding in the three organic systems until late July 
when competition from the crop canopy was sufficient to prevent weed growth.

\subsection{Fly oviposition}

Oviposition of $D$. radicum first and second generation was assessed 2007-2009 on 12 plants per plot, i.e. plant no. 4, 7, 10 and 13 out of the 16 plants per row, in three rows of second, fourth and sixth bed, respectively. For the first generation, plants of the second row of each of the three beds were sampled while plants of the first row of each of the three beds were sampled for the second generation. Once a week, the top soil was sampled with a spoon to a depth of $1 \mathrm{~cm}$ and in a radius of $3 \mathrm{~cm}$ around the stem of each selected plant. The soil samples were placed in separate plastic cups, fitted with a lid and kept cool in a box. The samples were stored at $5{ }^{\circ} \mathrm{C}$ until eggs were counted. Counting was done by pouring small portions of the soil into a beaker with tap water. Eggs were removed from the water surface with a fine paint brush. When no more eggs were visible the water was stirred and emerging eggs were removed until no more appeared.

Oviposition of the first generation was monitored for 3 weeks after transplanting the plants in the rows in mid May. During the flight of the second generation soil was sampled once a week for 3-4 weeks. Flight of the second generation was estimated using the on-line temperature dependent forecasting model provided by PlanteInfo (www.planteinfo.dk), which is an information and decision support system used by Danish farmers and agricultural advisers. Generally, the second generation of $D$. radicum was monitored from mid July onwards.

\subsection{Overwintering individuals}

In late October or early November 2006-2009 cabbage root systems and surrounding soil were sampled few days after harvest to estimate the number of overwintering $D$. radicum pupae in the plots. In each plot 10-12 root systems were collected inside cylindrical soil cores ( $14 \mathrm{~cm}$ in diameter, $16 \mathrm{~cm}$ deep), which were placed individually in polyethylene bags. Roots were selected arbitrarily in the central part of each plot avoiding plants that had been sampled for eggs. The soil cores were kept at $5{ }^{\circ} \mathrm{C}$ for $2-3$ months. Soil and root of each core was washed and sieved (mesh size $1 \mathrm{~mm}$ ) and pupariae were collected. The puparia from each sample were placed on a nylon mesh (mesh size $1 \mathrm{~mm}$ ) and kept moist in a beaker with perforated lid. The beakers were incubated at $20^{\circ} \mathrm{C}$ in a climate cabinet and emerging insects were counted. These included $D$. radicum and the parasitoids $T$. rapae and $A$. bilineata. Unhatched puparia were dissected under a stereo microscope for inspection of contents.

\subsection{Egg predation}

Predation of fly eggs in the four systems was assessed in 2007 and 2008 using sentinel eggs placed in the experimental plots. Eggs from the house fly Musca domestica L. (Diptera: Muscidae) were used as surrogates for D. radicum eggs following Prasad and Snyder (2004, 2006). House fly eggs originated from a continuous rearing at the Danish Pest Infestation Laboratory, Aarhus University, Sorgenfri, Denmark. Eggs were harvested and immediately frozen at $-20^{\circ} \mathrm{C}$ and used for field experiments after $1-2$ weeks. Sentinel egg units were prepared by placing ten eggs on a $1 \mathrm{~cm} \times 1 \mathrm{~cm}$ card of moist compressed sphagnum pot fitted with a wooden toothpick. The cards were kept frozen overnight. In the experimental plots, an area of soil surface within $5 \mathrm{~cm}$ from a cabbage plant was smoothened and each card was placed eggs facing upwards by inserting the toothpick in the soil. Each card was covered with a thin layer of soil particles $(0.2-0.3 \mathrm{~cm}$ deep). Six cards were placed in each plot in second, fourth and sixth bed of each plot by plants no. 5 and no. 11. Each card was fitted with a protecting roof made of a $6 \mathrm{~cm}$ semi-transparent plastic lid mounted on an $8 \mathrm{~cm}$ nail. In each plot, one to two controls were placed consisting of a card with fly eggs surrounded by a transparent plastic cylinder open at the top (diameter $9 \mathrm{~cm}$ ) that was pressed $1-2 \mathrm{~cm}$ into the soil to exclude epigeal predators. The sentinel eggs were exposed in the plots for $24 \mathrm{~h}$ at one occasion in May and two occasions in July of each year. Each card and surrounding soil was removed and placed in an individual lidded cup and kept cool for transportation. The cups with soil were frozen until the remaining numbers of eggs were estimated. Only complete and undamaged eggs were scored as remaining eggs.

\subsection{Activity-density of egg predators}

During the exposure of sentinel eggs for predation activitydensity of ground-dwelling predators was assessed by pitfall trapping in the plots. Transparent plastic cups (diameter $9 \mathrm{~cm}$ ) were filled with $100 \mathrm{ml}$ of a mixture of 1:1 ethylene glycol and tap water. Two traps were placed in third, fifth and seventh bed between plant no. 4 and 5, and no. 12 and 13, respectively, yielding six traps per plot. Traps were placed in the plots at the same day as sentinel eggs were exposed. The pitfall traps were left for 3 days and then removed, lidded and transported to the laboratory where they were placed at $5{ }^{\circ} \mathrm{C}$ until the arthropods were sorted and placed in $70 \%$ ethanol for storage. Carabid beetles were identified to species level and staphylinids were identified to subfamilies and sorted in size categories. For each pitfall trap small carabids belonging to Bembidion lampros (Herbst), Bembidion tetracolum Say, Bembidion quadrimaculatum (L.), Bembidion obtusum Serville, Trechus quadristriatus (Schrank), T. discus (F.) and T. micros (Herbst) were collectively grouped as "small beetles" together with all staphylinids of subfamily Aleocharinae measuring $8 \mathrm{~mm}$ or less in length following Prasad and Snyder (2004, 2006).

\subsection{Data analyses}

The number $(+1)$ of eggs laid and overwintering puparia per plant were $\log _{e}$-transformed and analyzed by mixed models in PROC MIXED in SAS with random effects of experimental field and experimental plot adjusting degrees of freedom by Satterthwaite formulae. For oviposition data, collection plant was also included as random factor. Fixed effects were farming system and week of collection. Mixed models were also applied to the data from individual pitfall trappings of small beetles after $\log _{\mathrm{e}}$-transformation as well as for selected carabid species.

Proportions of overwintering puparia harbouring parasitoids and proportions of fly eggs recovered in egg predation experiments were analyzed by logistic regression models with random effects of field and experimental plot using PROC GLIMMIX in SAS testing for fixed effect of farming system for parasitoids, and of farming system and experimental week for egg predation.

Egg survival success until pupation in 2007-2009 was estimated as the number of overwintering puparia in each plot divided by the number of eggs laid in the same plot during second generation oviposition. These proportions were analyzed by logistic regression models with random effects of field using PROC GLIMMIX in SAS testing for fixed effect of farming system, year and farming system $\times$ year.

Significant effects $(p<0.05)$ were tested by lsmeans and adjusted by the Tukey-Kramer adjustment to identify pair-wise differences. 


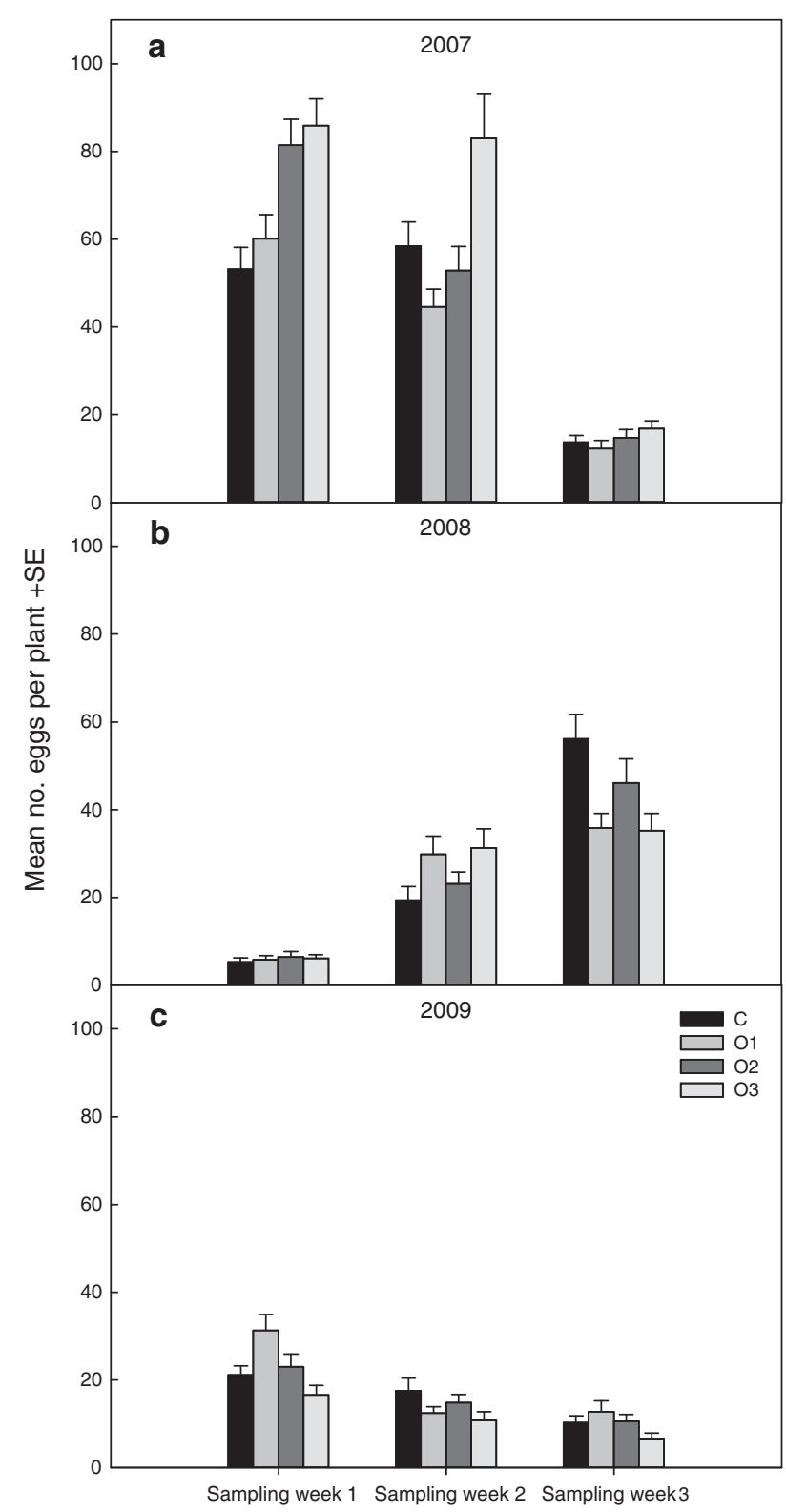

Fig. 1. Mean number (+S.E.) of second generation $D$. radicum eggs per plant per sampling week in 2007 (a), 2008 (b) and 2009 (c) in four farming systems (abbreviations cf. Table 1 ).

\section{Results}

Oviposition by first generation $D$. radicum varied over the 3 weeks of sampling in 2007 with highest levels in system $C$ during the first week (10.3 eggs/plant) and in systems $\mathrm{O} 2$ and $\mathrm{O} 3$ in the third week (10.8 eggs/plant) with a significant farming system and week interaction $\left(F_{6,323}=9.66 ; p<0.0001\right)$. For second generation oviposition in 2007 significant effects of farming system $\left(F_{3,99.2}=7.06 ; p=0.0002\right)$ and sampling week $\left(F_{2,336}=305.05\right.$; $p<0.0001$ ) were found (Fig. 1a). Oviposition was significantly higher in $\mathrm{O} 3$ compared to $\mathrm{C}$ and $\mathrm{O} 1$ (Tukey-Kramer adjustment: $p<0.01$ ). Egg laying activity decreased from first to second to third week (Tukey-Kramer adjustment: $p<0.005$ ).

In 2008, first generation oviposition continued through the 3 weeks of sampling (3.5-8.5 eggs/plant/week) with an overall farming system and week interaction $\left(F_{6,332}=3.95 ; p=0.0008\right)$. There was no effect of farming system on second generation oviposition $\left(F_{3,7.99}=0.02 ; p=0.9955\right)$, but significant effect of sampling

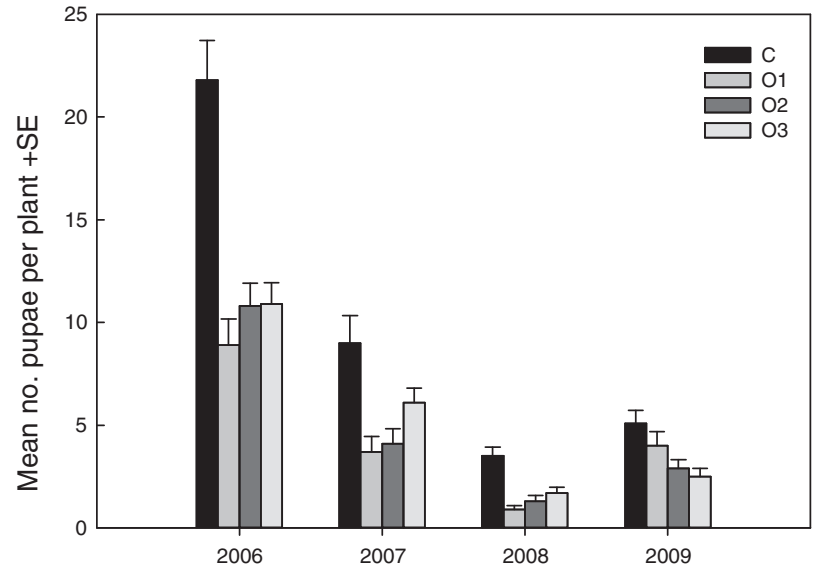

Fig. 2. Mean number (+S.E.) of D. radicum puparia per plant 2006-2009 in four farming systems (abbreviations cf. Table 1 ).

week $\left(F_{3,473}=156.54 ; p<0.0001\right)$ with different levels of oviposition among all 4 weeks (Tukey-Kramer adjustment: $p<0.0001$; Fig. 1b).

Oviposition of first generation D. radicum in 2009 was affected by farming system $\left(F_{3,5.98}=14.05 ; p=0.0041\right)$ and sampling week $\left(F_{2,336}=11.84 ; p<0.0001\right)$ but not their interaction $\left(F_{6,336}=0.86 ; p=0.5250\right)$. Significantly fewer eggs were laid in O3 (1.3-2.2 eggs/plant/week) than in the other three systems (4.1-7.8 eggs/plant/week; Tukey-Kramer adjustment: $p<0.02$ ) and overall oviposition was higher in the third week than in the two first weeks of sampling (Tukey-Kramer adjustment: $p<0.01$ ). Oviposition by second generation $D$. radicum was significantly affected by farming system $\left(F_{3,50.7}=6.39 ; p=0.0009\right.$; Fig. $\left.1 \mathrm{c}\right)$ and sampling week $\left(F_{2,292}=40.58 ; p<0.0001\right)$ and not their interaction $\left(F_{6,292}=0.74 ; p=0.6141\right)$. As in the first generation, significantly fewer eggs were laid in 03 compared to the other three systems (Tukey-Kramer adjustment: $p<0.01$ ) and overall oviposition decreased from the first to second to third week of sampling (Tukey-Kramer adjustment: $p<0.005$ ). In summary, no consistent effect of farming system on oviposition was seen over the 3 years of sampling, with most eggs being laid in $\mathrm{O} 3$ in 2007, no differences observed in 2008, while fewest eggs were laid in 03 in 2009. Over the 3 years, the overall levels of oviposition decreased at the field site (Fig. 1).

After the first growing season of the field experiment in 2006, the numbers of overwintering $D$. radicum puparia in the soil around cabbage plants were significantly affected by the farming system $\left(F_{3,5.89}=6.32 ; p=0.0284 ;\right.$ Fig. 2$)$. Significantly more overwintering puparia were found in the conventional system $C$ compared to the organic system 01 (Tukey-Kramer adjustment: $p=0.0239$ ) and numbers of puparia in $\mathrm{C}$ compared to $\mathrm{O} 2$ and $\mathrm{O} 3$ were close to be significantly higher (Tukey-Kramer adjustment: $p=0.0779$ and $p=0.1055$, respectively). In 2007 , there was no significant effect of farming system on the number of overwintering puparia $\left(F_{3,6}=2.37 ; p=0.1697\right.$; Fig. 2$)$. However, significant effects of farming system were found in the following two seasons, with most puparia per plant in $\mathrm{C}$ compared to the three organic systems in $2008\left(F_{3,6}=11.54 ; p=0.0067\right.$; Fig. 2 , Tukey-Kramer adjustment; $p<0.05)$, and in $2009\left(F_{3,138}=4.63 ; p=0.0040\right.$; Fig. 2$)$ with more puparia collected from $C$ than from $\mathrm{O} 2$ and $\mathrm{O} 3$ (Tukey-Kramer adjustment: $p<0.03$ ).

The estimated proportions of second generation $D$. radicum eggs reaching the pupal stage in each plot ranged between 0.010 and 0.103 and these proportions were significantly affected by a farming system and year interaction $\left(F_{6,22}=3.58 ; p=0.0126\right)$. In 2007 and 2008, survival rates were significantly higher in $C$ compared 


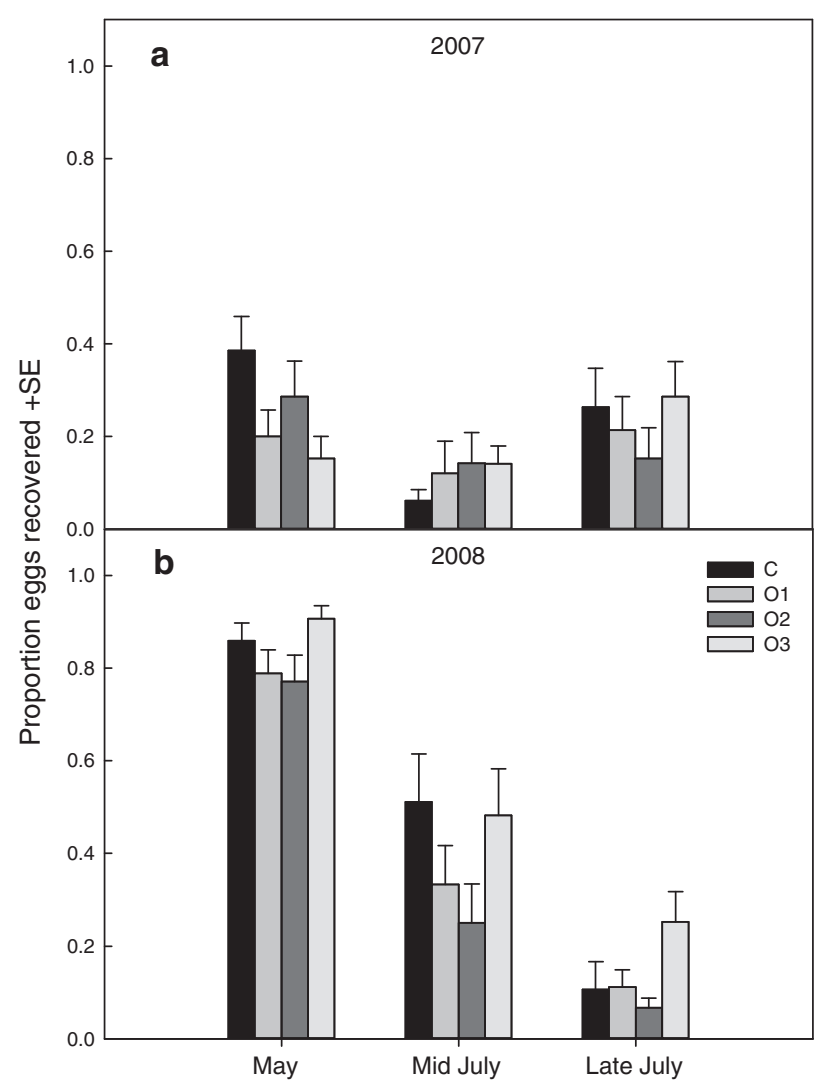

Fig. 3. Mean proportions (+S.E.) of recovered sentinel $M$. domestica eggs at three occasions in 2007 (a) and 2008 (b) in four farming systems (abbreviations cf. Table 1).

to all three organic systems, while the estimated survival rate in $C$ in 2009 was significantly higher than in 01 and 02 (Tukey-Kramer adjustment: $p<0.05$ ).

\subsection{Parasitoids and predators}

Mean proportions ( \pm S.E.) of the overwintering $D$. radicum puparia containing parasitoids ranged from $0.265( \pm 0.087)$ to 0.595 $( \pm 0.027)$ per farming system, but were always above 0.5 in 02 . However, in neither of the 4 years 2006-2009 significant differences in proportions of puparia with parasitoids were found among the farming systems. Parasitoids belonged either to T. rapae or A. bilineata in all 4 years, and the relative distributions of the two parasitoid species between parasitized puparia varied significantly among years with $T$. rapae constituting $91.0 \%$ of all parasitoids in 2006, 46.0\% in 2007, 78.8\% in 2008 and $40.0 \%$ in 2009 $\left(\chi^{2}=401.1185 ; \mathrm{df}=3 ; p<0.0001\right)$. In 3 of the 4 years, a trend was indicated that highest proportions of $T$. rapae among the parasitoids were found in 03 , but this was only significant in 2006 and close to significance ( $p=0.0512)$ in 2009 (Table 2 ).

Egg predation rates were estimated as proportions of fly eggs recovered after $24 \mathrm{~h}$ exposure in the plots, thus the more eggs recovered the less predation estimated. The recovered mean proportions of control eggs enclosed by plastic cylinders ranged between 0.86 and 0.93 in 2007 and 0.92 and 1.0 in 2008, which on all occasions were significantly higher than freely exposed eggs in the four farming systems (May 2007: $p<0.02$; July 2007: $p<0.0001$; May 2008: $p<0.001$; and July 2008: $p<0.0001$ ). The control treatments were therefore excluded from the data, which were then analyzed for system effects in four mixed models for each of the four oviposition periods. In May 2007, there was a significant effect of farming system $\left(F_{3,52}=7.75 ; p=0.0002\right.$; Fig. 3a $)$ with more eggs being recovered in $\mathrm{C}$ than in $\mathrm{O} 1$ and $\mathrm{O} 3$ (Tukey-Kramer adjustment: $p=0.0057$ and $p=0.0003$, respectively), and more in $\mathrm{O} 2$ than in $\mathrm{O} 3$ (Tukey-Kramer adjustment: $p=0.0427$ ). A significant interaction between farming system and experimental week existed for July $2007\left(F_{3,46}=3.19 ; p=0.0324\right)$, but the only significant differences in egg recovery were seen between the two experimental weeks in $C$ (Tukey-Kramer adjustment: $p=0.0059$ ) and in $\mathrm{O} 3$ (Tukey-Kramer adjustment: $p=0.0295$ ) with recovery being highest in the latter week (Fig. 3a). For the experimental week in May 2008 egg recovery was generally high (Fig. 3b) and a significant farming system effect was found $\left(F_{3,62}=4.61 ; p=0.0056\right)$ with higher egg recovery in $\mathrm{O} 3$ compared to $\mathrm{O} 1$ and $\mathrm{O} 2$ (Tukey-Kramer adjustment: $p=0.0225$ and $p=0.0084$, respectively). In July 2008 , there was a significant interaction between farming system and experimental week $\left(F_{3,65}=5.11 ; p=0.0031\right)$. However, all significant differences were between the two experimental weeks and no significant differences were found among farming systems within individual weeks. Overall, significant egg predation was found in all four farming systems, but no consistent differences among the systems were seen although a trend was indicated that predation in 2008 was lowest in $\mathrm{O} 3$ (Fig. 3b).

Numbers of selected species of small carabids combined with individuals $<8 \mathrm{~mm}$ of Aleocharinae ("small beetles") caught per trap were in 2007 affected by a significant interaction between farming system and sampling week $\left(F_{6,196}=7.64 ; p<0.0001\right)$ indicating differential patterns of catches among farming systems over time. In May, a mean ( \pm S.E.) of $20.1( \pm 2.26)$ small beetles were caught per trap in $\mathrm{O} 2$ which was significantly higher than in the other three farming systems (Tukey-Kramer adjustment: $p<0.001$ ). No differences were found among farming systems in the two sampling weeks in July 2007. For collections in 2008, there was no significant interaction between farming system and sampling week $\left(F_{6,201}=1.98 ; p=0.07\right)$ but individual effects of farming system $\left(F_{3,201}=12.27 ; p<0.0001\right)$ and sampling week $\left(F_{2,201}=32.03\right.$; $p<0.0001)$. During the three sampling weeks, mean beetle numbers $( \pm$ S.E.) per trap ranged between $17.8( \pm 1.42)$ and $26.5( \pm 2.30)$ in $\mathrm{O} 2$ which were significantly higher than in the three other systems (Tukey-Kramer adjustment: $p<0.05$ ). Total catches in 2008 were significantly different among the 3 weeks, lowest in May and highest during the first collection in July (Tukey-Kramer adjustment: $p<0.0004$ ).

Total egg predation and number of potential egg predators in each experimental plot were not significantly correlated in May 2007 (Spearman correlation coefficient $=0.28142 ; p=0.3756$; $n=12$ ), July 2007 (Spearman correlation coefficient $=-0.16204$; $p=0.4494 ; n=24)$, May 2008 (Spearman correlation coefficient $=-0.44211 ; p=0.1501 ; n=12$ ) or in July 2008 (Spearman correlation coefficient $=0.31236 ; p=0.1373 ; n=24$ ).

For three of the four Bembidion species caught, most individuals were found in May in both years, and pitfall catches for May in 2007 and 2008 of each of the three species were analyzed separately. Significant effects of farming system (B. lampros: $F_{3,66}=19.62$, $p<0.0001$; B. quadrimaculatum: $F_{3,66}=20.10, p<0.0001$; B. tetracolum: $\left.F_{3,66}=24.19, p<0.0001\right)$ and year (B. lampros: $F_{1,68}=6.55$, $p=0.0127 ; B$. quadrimaculatum: $F_{1,68}=5.09, p=0.0273 ; B$. tetracolum: $F_{1,68}=5.88, p=0.0180$ ) were found for each species while none of the interactions were significant. Thus farming system effects were consistent between years, but overall catches were different between the 2 years. For all the three species, most individuals were caught in the organic system 02 (Table 3 ). Individuals of the generalist predator Pterostichus melanarius (Illiger) were predominantly caught in July in both 2007 and 2008 with no significant interaction between farming system and year $\left(F_{3,210}=2.04\right.$, $p=0.1088)$. During July, means $( \pm$ S.E.) of individuals caught per pitfall trap equalled $2.9( \pm 0.34)$ in $C, 3.6( \pm 0.46)$ in $01,3.8$ $( \pm 0.39)$ in 02 , and $3.0( \pm 0.34)$ in 03 . No differences were seen in 
Table 2

Mean proportions (S.E.) of parasitized puparia harbouring Trybliographa rapae in each of four farming systems per year.

\begin{tabular}{|c|c|c|c|c|c|c|}
\hline \multirow[t]{2}{*}{ Year } & \multicolumn{4}{|c|}{ Farming system ${ }^{\mathrm{a}}$} & \multicolumn{2}{|c|}{ Summary statistics } \\
\hline & C & 01 & $\mathrm{O} 2$ & $\mathrm{O} 3$ & F-Value & $p$ \\
\hline 2006 & $0.838(0.023)$ & $0.882(0.044)$ & $0.951(0.020)$ & $0.971(0.017)$ & $F_{3,98}=4.67$ & 0.0043 \\
\hline 2007 & $0.604(0.049)$ & $0.457(0.091)$ & $0.420(0.082)$ & $0.340(0.060)$ & $F_{3,82}=1.34$ & 0.2683 \\
\hline 2008 & $0.800(0.069)$ & $0.563(0.175)$ & $0.806(0.092)$ & $0.871(0.057)$ & $F_{3,49}=0.68$ & 0.5678 \\
\hline 2009 & $0.312(0.067)$ & $0.269(0.070)$ & $0.427(0.085)$ & $0.675(0.094)$ & $F_{3,86}=2.69$ & 0.0512 \\
\hline
\end{tabular}

a Abbreviations cf. Table 1.

Table 3

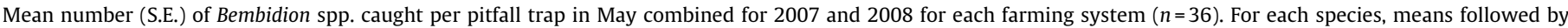
different letters are significantly different (Tukey-Kramer adjustment, $p<0.05$ ).

\begin{tabular}{|c|c|c|c|c|}
\hline & \multicolumn{4}{|c|}{ Farming system $^{\mathrm{a}}$} \\
\hline & $\mathrm{C}$ & 01 & $\mathrm{O} 2$ & $\mathrm{O} 3$ \\
\hline Bembidion lampros & $3.3(0.46) \mathrm{a}$ & $3.3(0.39) a$ & $6.1(0.70) b$ & $1.4(0.22) \mathrm{c}$ \\
\hline Bembidion quadrimaculatum & $0.9(0.19) \mathrm{a}$ & $2.3(0.39) b$ & $4.1(0.51) c$ & $1.4(0.17) \mathrm{ab}$ \\
\hline Bembidion tetracolum & $0.6(0.14) \mathrm{a}$ & $1.3(0.36) \mathrm{a}$ & $2.9(0.44) b$ & $0.2(0.09) \mathrm{c}$ \\
\hline
\end{tabular}

a Abbreviations cf. Table 1.

activity-density of $P$. melanarius among the four farming systems $\left(F_{3,65.9}=1.52, p=0.2178\right)$ while the effect of year was significant $\left(F_{1,210}=148.70, p<0.0001\right)$ with fewest beetles caught in 2008 .

\section{Discussion}

The field experiment demonstrated that the three organically farmed cabbage production systems provided enhanced regulation of $D$. radicum measured by puparia/egg ratios over a conventionally farmed system. However, no clear differences were observed among the four experimental cropping systems on $D$. radicum oviposition. The intercropped strips of green manure in $\mathrm{O} 3$ were hypothesized to reduce the oviposition by $D$. radicum females as documented for intercropped clover within Brassica crops (Tukahirwa and Coaker, 1982; Finch and Collier, 2000a; Bjorkman et al., 2007, 2010), but oviposition was only found to be lowest in O3 in 2009 while it was highest in 2007. Tukahirwa and Coaker (1982) showed that the distance from host plant to intercropped non-host plant should be $<50 \mathrm{~cm}$ to significantly reduce oviposition rates of $D$. radicum. The maximum distance in the present study was $40 \mathrm{~cm}$. However, cabbage plants were only neighbouring green manure strips to one side, and the intercropped strips in $\mathrm{O} 3$ may thus have been inappropriately positioned to yield a continuous confusion effect as described by Finch and Collier (2000a). These strips are therefore unlikely to reduce oviposition of $D$. radicum in a pest management strategy in cabbage cropping systems.

Since oviposition in $\mathrm{C}$ was not consistently higher than in the three organic systems the results indicate that $D$. radicum survival from egg to pupation was increased in C compared to the organic systems. In the present study, small beetle abundance, including Bembidion spp., was generally highest in 02 , suggesting enhanced predation in this organic system. The method of using sentinel $M$. domestica eggs proved useful for evaluating predation rates, but it was not possible to attribute the indicated superior survival of $D$. radicum from egg to pupation in $C$ to reduced egg predation in the conventional system compared to the organic systems. Lack of correlations between egg removal and abundance of egg predators in experimental plots was also reported by Prasad and Snyder (2006) and Bjorkman et al. (2010) despite increased pupal production when potential egg predators were excluded (Bjorkman et al., 2010). The egg predation effect of small beetles could be compromised either by the presence of alternative prey or intraguild predation by large carabids such as $P$. melanarius (Prasad and Snyder, 2006). However, activity-densities of
$P$. melanarius were equal among farming systems in the present study. Habitat heterogeneity provided by the intercropped strip of green manure in $\mathrm{O} 3$ did not benefit small beetles known to be egg predators, particularly Bembidion spp. which are more abundant in open ground habitats than in areas with increased ground cover (Eyre et al., 2009; Bjorkman et al., 2010). Although organic systems $\mathrm{O} 1$ and $\mathrm{O} 2$ had comparable ground cover small beetles were most abundant in $\mathrm{O} 2$. The combination of low slurry input and green manures in organic cropping systems may have benefitted small predatory beetles, though no significant differences in organic matter contents of the soil of $\mathrm{O} 1$ and $\mathrm{O} 2$ were found $(\mathrm{K}$. Thorup-Kristensen, unpubl.).

Parasitism by parasitoids in second generation puparia were unaffected by the experimental farming practices. Data indicated a relative dominance of $T$. rapae in some years, and then mostly in O3, suggesting potential benefits of floral nectar resources in the strips of green manure.

Slurry was applied to all three organic systems showing reduced D. radicum puparia/egg ratios compared to the conventional system $\mathrm{C}$, which was fertilized by synthetic fertilizers and received the highest total amounts of nutrients. Although 01 received a higher external input of nitrogen than $\mathrm{O} 2$ and $\mathrm{O} 3, \mathrm{D}$. radicum survival estimates were comparable among the three organic systems indicating that the amendment of organic fertilizer may have contributed to the observed effect. The organic system $\mathrm{O} 2$ exhibited reduced nitrogen leaching compared to $\mathrm{C}$ and $\mathrm{O} 1$ (Thorup-Kristensen et al., 2012) and may provide most promise as a sustainable approach for organic cabbage cropping systems as it additionally benefitted small predatory beetles.

\section{Acknowledgements}

Christina Wolsted, Camilla Falk, Ida Mikkelsen and Marie-Louise Simonsen provided technical assistance in the field and laboratory. Tove Steenberg and Lise S. Hansen kindly provided M. domestica eggs. We thank Christian Ritz for statistical advice. Comments by anonymous reviewers improved the manuscript. This research was funded by the Danish DARCOF III Programme for Research in Organic Farming.

\section{References}

Alyokhin, A., Porter, G., Groden, E., Drummond, F., 2005. Colorado potato beetle response to soil amendments: a case in support of the mineral balance hypothesis? Agric. Ecosyst. Environ. 109, 234-244. 
Båth, B., Kristensen, H.L., Thorup-Kristensen, T., 2008. Root pruning reduces root competition and increases crop growth in a living mulch cropping system. J. Plant Interact. 3, 211-221.

Birkhofer, K., Bezemer, T.M., Bloem, J., Bonkowski, M., Christensen, S., Dubois, D., Ekelund, F., Fliessbach, A., Gunst, L., Hedlund, K., Mader, P., Mikola, J., Robin, C., Setala, H., Tatin-Froux, F., van der Putten, W.H., Scheu, S., 2008. Long-term organic farming fosters below and aboveground biota: implications for soil quality, biological control and productivity. Soil Biol. Biochem. 40, 2297-2308.

Bjorkman, M., Hamback, P.A., Hopkins, R.J., Ramert, B., 2010. Evaluating the enemies hypothesis in a clover-cabbage intercrop: effects of generalist and specialist natural enemies on the turnip root fly (Delia floralis). Agric. Forest Entomol. 12, $123-132$.

Bjorkman, M., Hamback, P.A., Ramert, B., 2007. Neighbouring monocultures enhance the effect of intercropping on the turnip root fly (Delia floralis). Entomol. Exp. Appl. 124, 319-326.

Bonsall, M.B., Hassell, M.P., Reader, P.M., Jones, T.H., 2004. Coexistence of natural enemies in a multitrophic host-parasitoid system. Ecol. Entomol. 29, 639-647.

Crowder, D.W., Northfield, T.D., Strand, M.R., Snyder, W.E., 2010. Organic agriculture promotes evenness and natural pest control. Nature 466, 109-123.

Eigenbrode, S.D., Pimentel, D., 1988. Effects of manure and chemical fertilizers on insect pest populations on collards. Agric. Ecosyst. Environ. 20, 109-125.

Eyre, M.D., Labanowska-Bury, D., Avayanos, J.G., White, R., Leifert, C., 2009. Ground beetles (Coleoptera, Carabidae) in an intensively managed vegetable crop landscape in eastern England. Agric. Ecosyst. Environ. 131, 340-346.

Finch, S., 1996. Effect of beetle size on predation of cabbage root fly eggs by ground beetles. Entomol. Exp. Appl. 81, 199-206.

Finch, S., Collier, R.H., 2000a. Host-plant selection by insects - a theory based on 'appropriate/inappropriate landings' by pest insects of cruciferous plants. Entomol. Exp. Appl. 96, 91-102.

Finch, S., Collier, R.H., 2000b. Integrated pest management in field vegetable crops in northern Europe - with focus on two key pests. Crop Protect. 19, 817-824.

Finch, S., Skinner, G., 1980. Mortality of overwintering pupae of the cabbage root fly (Delia brassicae). J. Appl. Ecol. 17, 657-665.

Garratt, M.P.D., Wright, D.J., Leather, S.R., 2010. The effects of organic and conventional fertilizers on cereal aphids and their natural enemies. Agric. Forest Entomol. 12, 307-318.

Garratt, M.P.D., Wright, D.J., Leather, S.R., 2011. The effects of farming system and fertilisers on pests and natural enemies: a synthesis of current research. Agric. Ecosyst. Environ. 141, 261-270.
Hooks, C.R.R., Johnson, M.W., 2003. Impact of agricultural diversification on the insect community of cruciferous crops. Crop Protect. 22, 223-238.

Hsu, Y.T., Shen, T.C., Hwang, S.Y., 2009. Soil fertility management and pest responses: a comparison of organic and synthetic fertilization. J. Econ. Entomol. 102 $160-169$.

Hughes, R.D., 1959. The natural mortality of Erioischia brassicae (Bouche) (Diptera, Anthomyiidae) during the egg stage of the first generation. J. Anim. Ecol. 28, 343-357.

Hummel, J.D., Dosdall, L.M., Clayton, G.W., Harker, K.N., O’Donovan, J.T., 2010. Responses of the parasitoids of Delia radicum (Diptera: Anthomyiidae) to the vegetational diversity of intercrops. Biol. Control 55, 151-158.

Jones, T.H., Hassell, M.P., Pacala, S.W., 1993. Spatial heterogeneity and the population dynamics of a host parasitoid system. J. Anim. Ecol. 62, 251-262.

Landis, D.A., Wratten, S.D., Gurr, G.M., 2000. Habitat management to conserve natural enemies of arthropod pests in agriculture. Annu. Rev. Entomol. 45, 175-201.

Prasad, R.P., Snyder, W.E., 2004. Predator interference limits fly egg biological control by a guild of ground-active beetles. Biol. Control 31, 428-437.

Prasad, R.P., Snyder, W.E., 2006. Polyphagy complicates conservation biological control that targets generalist predators. J. Appl. Ecol. 43, 343-352.

Staley, J.T., Stewart-Jones, A., Pope, T.W., Wright, D.J., Leather, S.R., Hadley, P., Rossiter, J.T., van Emden, H.F., Poppy, G.M., 2010. Varying responses of insect herbivores to altered plant chemistry under organic and conventional treatments. Proc. R. Soc. B. 277, 779-786.

Straub, C.S., Finke, D.L., Snyder, W.E., 2008. Are the conservation of natural enemy biodiversity and biological control compatible goals? Biol. Control 45, 225-237.

Thorup-Kristensen, K., Dresbøll, D.B., Kristensen, H.L., 2012. Crop yield, root growth, and nutrient dynamics in a conventional and three organic cropping systems with different levels of external inputs and $\mathrm{N}$ re-cycling through fertility building crops. Eur. J. Agron. 37, 66-82.

Tukahirwa, E.M., Coaker, T.H., 1982. Effect of mixed cropping on some insect pests of Brassicas: reduced Brevicoryne brassicae infestations and influences on epigeal predators and the disturbance of oviposition behavior in Delia brassicae. Entomol. Exp. Appl. 32, 129-140.

Wishart, G., Doane, J.F., Maybee, G.E., 1956. Notes on beetles as predators of eggs of Hylemya brassicae (Bouche) (Diptera: Anthomyiidae). Can. Entomol. 88 634-639.

Zehnder, G., Gurr, G.M., Kuhne, S., Wade, M.R., Wratten, S.D., Wyss, E., 2007. Arthropod pest management in organic crops. Annu. Rev. Entomol. 52, 57-80. 